\title{
Effect of bovine hydroxyapatite on early stages of bone formation
}

\author{
Efeito da hidroxiapatita bovina no período inicial de \\ formação óssea
}

\begin{abstract}
Purpose: This study aimed to characterize the effect of bovine hydroxyapatite particles $(\mathrm{HA})$ on the early stages of bone repairing in a rat femur defect model.

Methods: A non-critical $2 \mathrm{~mm}$ diameter bone defect was made in both femurs of 25 male albino Wistar rats. The left femurs defects were filled with $\mathrm{HA}$ and the right femurs defects were just let to fill with blood. Five animals were sacrificed at the $1^{\text {st }}, 3^{\text {rd }}, 5^{\text {th }}, 7^{\text {th }}$ or $14^{\text {th }}$ post-surgery day and bone tissue sections were stained with hematoxylin and eosin for comparison of inflammatory response by light microscopy. Histomorphometrical analysis of the newly formed bone was evaluated at the three last periods, using independent t-student test to compare both groups at each period $(\alpha=0.05)$.

Results: Histological analyses showed same standard of bone repair on first and third day; however, from the fifth post-surgery day there was a higher deposit of collagen fibers surrounding the hydroxyapatite particles and a greater thickness of the opposite side periosteum. There was no significant histomorphometrical difference between groups at all periods.

Conclusion: It can be concluded that hydroxyapatite does not accelerate the early-stage of bone repairing, despite of induction of a higher deposit of collagen fibers.
\end{abstract}

Key words: Bone regeneration; biocompatible materials; hydroxyapatite

\section{Resumo}

Objetivo: $O$ objetivo deste estudo foi caracterizar o efeito das partículas de hidroxiapatita bovina $(H A)$ nos estágios iniciais da reparação óssea em modelo de defeito ósseo em fêmur de ratos.

Metdologia: Defeito ósseo não crítico de $2 \mathrm{~mm}$ de diâmetro foi feito em cada fêmur de 25 ratos Wistar albinos. O defeito do fêmur esquerdo foi preenchido com HA enquanto a cavidade direita foi preenchida apenas com sangue. Cinco animais foram sacrificados no $1^{\circ}$, $3^{\circ}, 5^{\circ}, 7^{\circ}$ e $14^{\circ}$ dia pós-cirúrgico. Os cortes histológicos do tecido ósseo foram corados com hematoxicilina e eosina para comparação da resposta inflamatória por microscopia óptica. Análise histomorfométrica do tecido ósseo neoformado foi avaliado nos três últimos períodos utilizando o teste + de Student para comparação de ambos os grupos em cada período de avaliação $(\alpha=0,05)$.

Resultados: A análise histológica mostrou o mesmo padrão de reparação óssea no $1^{\circ}$ e $3^{\circ}$ dia; entretanto, no $5^{\circ}$ dia pós-cirúrgico houve um maior depósito de fibras de colágeno ao redor dos cristais de hidroxiapatita e uma maior espessura do perióstio oposto. Não houve diferença histomorfométrica significativa entre os grupos em todos os períodos avaliados.

Conclusão: Pode ser concluído que a hidroxiapatita não acelera os estágios inicias da reparação óssea, apesar de induzir a um maior depósito de fibras de colágeno.

Palavras-chave: Reparação óssea; biomateriais; hidroxiapatita

\author{
Bruno Salles Sotto-Maior a \\ Plinio Mendes Senna a \\ Beatriz Julião V. Aarestrup b \\ Rosangela Almeida Ribeiro b \\ Neuza Maria de Souza Picorelli Assis ' \\ Altair Antoninha Del Bel Cury ${ }^{a}$
}

\begin{abstract}
a Department of Prosthodontics and Periodontology, Piracicaba Dental School, State University of Campinas, Piracicaba, SP, Brazil

b Juiz de Fora Dental School, Federal University of Juiz de Fora, Juiz de Fora, MG, Brazil
\end{abstract}

\author{
Correspondence: \\ Plinio Mendes Senna \\ Piracicaba Dental School \\ State University of Campinas \\ Department of Prosthodontics and Periodontology \\ Av. Limeira, 903 \\ Piracicaba, SP - Brazil \\ $13414-903$ \\ E-mail: psenna3@fop.unicamp.br
}

Received: March 3, 2011

Accepted: August 28, 2011

Conflict of Interest Statement: The authors state that there are no financial and personal conflicts of interest that could have inappropriately influenced their work.

Copyright: (C) 2011 Sotto-Maior et al.; licensee EDIPUCRS. This is an Open Access article distributed under the terms of the Creative Commons AttributionNoncommercial-No Derivative Works 3.0 Unported License. 


\section{Introduction}

The bone resorption normally associated with socket healing after tooth extraction can compromise the optimal positioning for dental implant placement. Therefore, several bone grafting have been used into fresh extraction sockets to the reestablishment of the alveolar ridge before the implant installation. The grafting materials are classified in four groups according to its source: autogenous (obtained from the same individual); allogenic (obtained from another individual within the same specie); alloplastic (synthetically produced); or xenogenic (obtained from another species) (1-4).

Autogenous bone is considered gold standard grafting material due to its ideal biologic properties, satisfying the osteogenic, osteoconductive and osteoinductive requirements $(1,2)$. It has being used in procedures for bone augmentation of atrophic maxillas and mandibles, surgery reconstructions and guided regeneration (5). However, the need of different surgical sites intervention, limited bone availability, higher morbidity, and longer recovery period are disadvantages that usually lead to the search for alternative biomaterials $(5,6)$.

Allogenic grafts are usually obtained from human bone bank and represent an alternative to the autogenous bone; however, the possibility of viral transmission and the risk of immunological reaction, favoring a higher resorption, limit their use (2). On the other hand, alloplastic materials, consisting of synthetic inorganic minerals obtained by calcium phosphates such as tricalcium phosphate and hydroxyapatite, do not have these disadvantages. However, alloplastic biomaterials are only osteoconductive and consequently do not have the potential of repairing critical size defects (7).

Xenogenic graft biomaterial is usually a bovine bone that is properly processed for deproteinization. This material mainly consists of bovine hydroxyapatite and has osteoconductive and osteoinductive properties $(4,8)$, allowing the new bone tissue to grow in the space between its mineral particles (4). Despite of its high success rates (9) the histological benefits involving its initial healing in bone defects is not yet clarified. Therefore, the aim of this study was to assess the effect of bovine hydroxyapatite filling on the early stages of bone repairing in a non-critical rat femur defect model.

\section{Methods}

\section{Experimental design}

Non-critical bone defects were surgically created on both femurs of 25 Wistar rats. The left femur defects (experimental group - EG) were filled with bovine hydroxyapatite $\left(\right.$ Genox $^{\circledR}$ Inorg, Baumer, SP, Brasil) and the right defects were just let to fill with blood (control group - CG). The animals were sacrificed with anesthetic overdose at the $1^{\text {st }}, 3^{\text {rd }}, 5^{\text {th }}, 7^{\text {th }}$ or $14^{\text {th }}$ post-surgery day $(n=5)$. The inflammatory response was qualitatively evaluated by light microscopy at the $1^{\text {st }}$, $3^{\text {rd }}$ and $5^{\text {th }}$. The new formed bone at the $5^{\text {th }}, 7^{\text {th }}$, and $14^{\text {th }}$ was histomorphometrically evaluated. All histologic and histomorphometric analysis were done by a blind examiner and both groups were compared at each post-operative period by the t-student test with significance level fixed at $5 \%$.

Femur defect model

After approval by the local ethics committee on animal research, 25 male Wistar rats, weighing between 160 and $220 \mathrm{~g}$, were kept in an environment with controlled temperature, light cycle and humidity. They were kept in groups of four per cage and received standard food and water "ad libitum".

The animals were sedated with $2 \%$ xylasine hydrochloride $\left(0.30 \mathrm{ml} / 100 \mathrm{~g}\right.$, ip - Rompum ${ }^{\circledR}$; Bayer, São Paulo, Brazil) and anesthetized with ketamine chloride $(0.15 \mathrm{ml} / 100 \mathrm{~g}$, ip Vetanarcol $^{\circledR}$; König, Avellaneda, Argentina) five minutes later. The femur bones were surgically exposed with a $40 \mathrm{~mm}$ longitudinal incision, dissecting skin, muscle and periosteum. Then, a non-critical bone defect $(2 \mathrm{~mm}$ diameter $\mathrm{x} 1 \mathrm{~mm}$ deep) was made at the medial third of the lateral face of each femur using a round hand steel bur with $2 \mathrm{~mm}$ diameter (KG Sorensen; São Paulo, Brazil). Profuse irrigation with sterile phosphate-buffered saline (PBS) was maintained throughout the drilling. After washing both surgical sites with PBS, the left femoral cavity was filled with hydroxyapatite while the right one was left to fill with blood. The muscles and periosteum flaps were repositioned, covering the bone defect, and sutured with Vicryl 4-0 (J\&J Ethicon; São José dos Campos, Brazil) while the skin flaps were closed with nylon sutures.

\section{Histological and histomorphometric evaluations}

The femurs were subsequently extracted and a segment including the bone defect region and $2 \mathrm{~mm}$ of adjacent healthy bone was cut transversely using a diamond saw and immediately immersed in $10 \%$ buffering formaldehyde solution for $24 \mathrm{~h}$ and decalcified in 10\% EDTA solution. The specimens were embedded in paraffin and the serial sections ( $6 \mu \mathrm{m}$ thickness) representing the experimental sites were cut with microtome in a mesio-distal plane and parallel to its long axis. Then, the sections were stained with hematoxylin and eosin.

The inflammatory response was qualitatively evaluated by light microscope (Jenamed 2, Carl Zeiss, Jena, Germany), at 40,100, 250 and 400 magnification by the same blind examiner. Both groups were compared at each post-operative period based on the cells type, extracellular matrix and the organization of the new formed bone tissue.

Three histological sections, one of each border of the bone defect (boundary mature compact bone and new formed bone tissue interface) and one of the middle of bone defect, were digitally captured with $40 \times$ magnification at $5^{\text {th }}, 7^{\text {th }}$ and $14^{\text {th }}$ post-operative days. These images were transmitted to a computer and subjected to the histomorphometric analysis by a blind examiner using Axiovision ${ }^{\circledR}$ (Version 4.5, Bethesda, EUA.) software. The sum of the total area $\left(\mu \mathrm{m}^{2}\right)$ of the new formed bone matrix was obtained by the mean value achieved at three pre-determined microscopic fields. 


\section{Results}

On the first post-surgery day, CG1 and EG1 showed a dense fibrin network embracing the inorganic bovine hydroxyapatite particles with acute inflammatory reaction containing a large number of mesenchymal, polymorphonuclear leukocytes, erythrocytes and vascular structures. Blood vessels associated with oedema formation were also observed (Fig. 1A and 1B) with presence of some mononuclear leukocytes (monocytes/macrophages).

On the third post-surgery day, the bone defect was occupied by coagulum characterized by a predominance of polymorphonuclear leukocytes and trapped in a denser fibrin network in both CG3/EG3 groups. However, the inflammatory process had lower intensity than CG1/EG1, with moderate edema volume in the lamina propria and several cells emanated from the bone marrow onto the bottom region of the cavity through a small passageway from the marrow cavity bone (Fig. 2A and 2B). Also, the periosteum opposite to the bone defect exhibited a notable cell proliferation.

On fifth day both groups showed a higher deposit of collagen fibers surrounding the HA particles and greater thickness of the opposite side periosteum in EG5. Also, the initial mineralization process was noticed in both groups with higher intensity of extracellular fibrillar matrix and osteoid production, which originate new immature bone (Fig. 3A and 3B). Osteoclasts were present on the surface of the bone defects walls as well as on adjacent and more distant HA particles granules.

The new formed bone area showed no significant statistical difference between groups at the evaluated periods $\left(P=0.695 ; P=0.228 ; P=0.576\right.$ respectively to the $5^{\text {th }}, 7^{\text {th }}$ and $14^{\text {th }}$ post-surgery day) (Fig. 4 ).
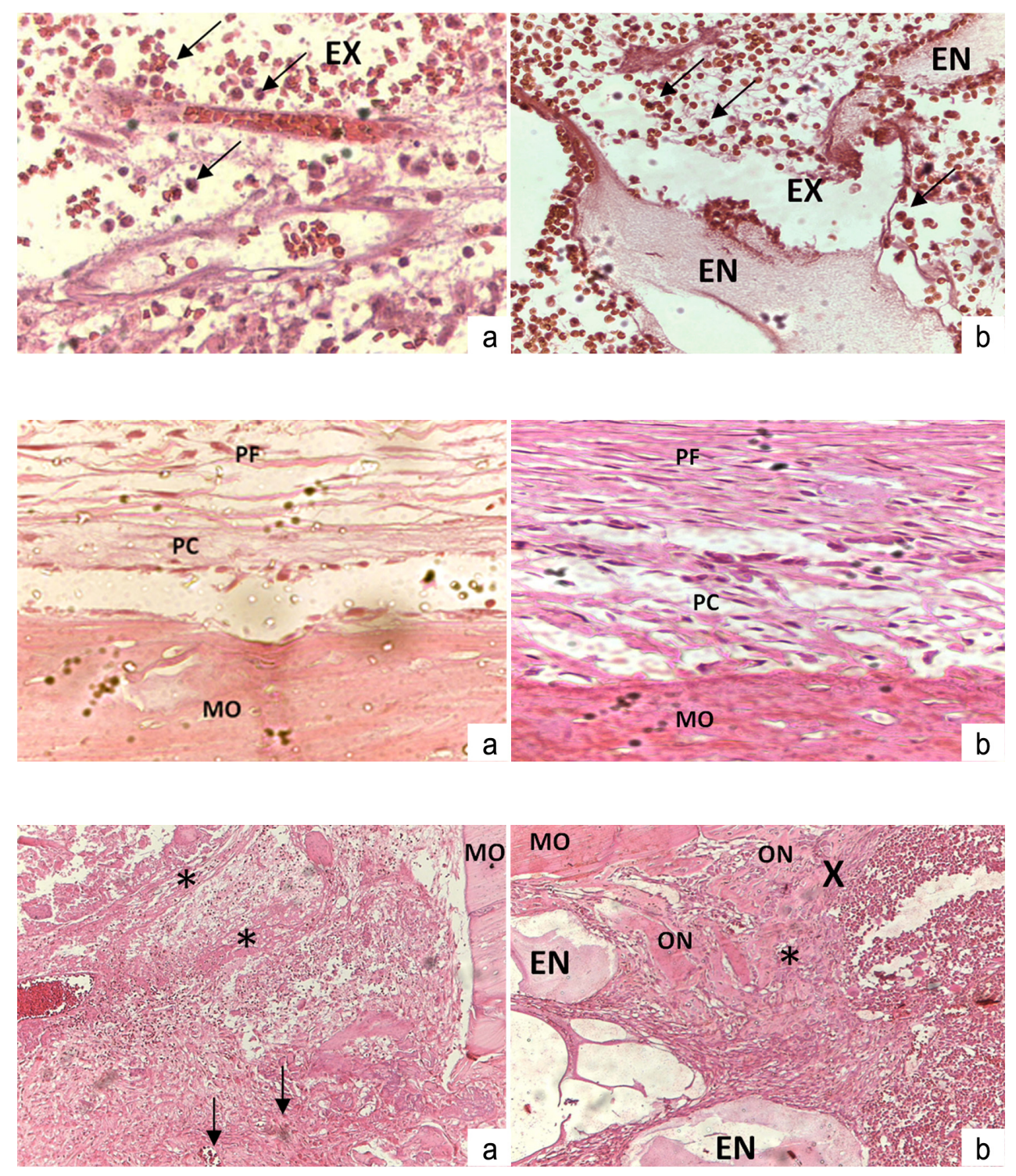

Fig. 1. Histological sections of CGI (a) and EG1 (b) at 1 st post-surgery day. Acute inflammatory infiltrate diffused in the lamina propria, composed predominantly of neutrophils (arrows) and exudative oedema (EX). In EG1 the graft particles (GP) can be seen.

Fig. 2. Histological sections of CG3 (a) and EG3 (b) at $3^{\text {st }}$ post-surgery day. Bone margin opposite to bone defect (BD); cellular periosteum (CP); fibrous periosteum (FP).

Fig. 3. Histological sections at $5^{\text {st }}$ post-surgery day. CG5 (a) presenting vascular neoformation (arrows) and collagen fibers $\left({ }^{*}\right)$ near the opposite margin of the bone defect (BD).

EG5 (b) also presents discrete osteoid production (x); bone neoformation (BN); graft particles (GP); newly formed bone (NB). 


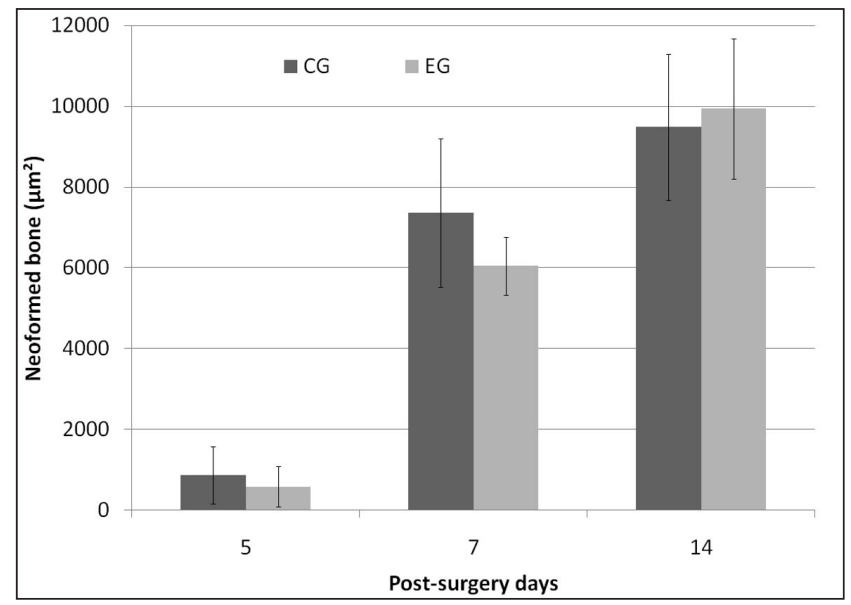

Fig. 4. Bone neoformation (mean \pm s.d.) at the different periods (CG - control group; EG - experimental group).

\section{Discussion}

The incorporation of bovine hydroxyapatite particles in non-critical bone defects caused several subsequent processes including: acute inflammation, formation of granulation tissue and provisional matrix. This rat model is a well established model for bone repairing studies, and it was chosen due to its easy handling and lower cost (4) despite of the bone healing in femurs differs from fresh sockets healing (15).

In order to exclude the possibility of hormonal influence, body growing or the presence of immature bone, the sample was constituted only by adult male rats. The non-critical defects were surgically created in order to evaluate the healing effects of hydroxyapatite presence with faster results (10). The removal of only one of the cortical allows the spontaneous bone regeneration by the body and the possibility to compare it to other studies.

Despite of the bone tissue has a remarkable regeneration potential to restore its original structure and mechanical properties $(11,12)$, surgical techniques combining the use of bone grafts and/or biomaterials have been developed to recover the normal anatomical shape and allow functional and physiological oral rehabilitation with the use of implants and/or conventional prostheses $(4,8,13)$. Autogenous bone graft is considered as gold standard for reconstruction of bone defects (5), since there is no immunological response or rejection while it is osteoinductor and osteoconductor. However, the need of surgical intervention in other bone sites, limited graft quantity, higher morbidity and longer recovery period increase the indications to use biomaterials $(5,6)$.

Within these grafting biomaterials, we can point out the allogenic, xenograft and alloplastic grafts $(7,14)$. The bovine hydroxyapatite used in this study was a xenograft bone obtained from deproteinized cancellous bone, which presents the advantages of unlimited quantity of material, lower surgical morbidity as it does not need a donor site, as well as osteoinductive and osteoconductive properties (15). This biomaterial is prepared by a chemical process that removes all organic material leaving an inorganic scaffold, composed of all natural bone minerals, such as hydroxyapatite, carbonate and phosphate $(4,15)$. The histological evaluations of $1^{\text {st }}, 3^{\text {rd }}$ and $5^{\text {th }}$ post-surgery day exhibited osteoid production in both femur groups, corresponding to the osteoblast proliferation and natural tissue repairing period. The osteoinductive potential of hydroxyapatite showed in previous reports $(4,15)$ was confirmed in this study by the higher deposit of collagen fibers surrounding the hydroxyapatite particles and greater thickness of the opposite side periosteum in EG3 and EG5. These characteristics are suggestive of mitotic potential and increase of the metabolic activity for a future protein synthesis, also reported by previous studies $(3,4,16,17)$.

The particles distribution of hydroxyapatite creates a porous structure, which allows migration and binding of osteogenic cells from the host organism. Therefore, the maintenance of a space for later bone formation through the mineral scaffold enables the osteoconductive property of this material $(4,15,16)$. This was seen at EG5 histological sections, in which a new formed bone was seen among hydroxyapatite particles.

However, in early stages of bone formation, histomorphometric analysis showed no statistical differences between groups. This may be explained by the necessity of reabsorption of the graft particles before the new bone matrix is deposited without any increase of bone formation velocity. Also, there is a smaller area for new bone formation, since the graft occupies part of the defect space. In addition, the smaller bone formation in the bone defect that received xenograft bovine bone is attributable to its properties of slow reabsorption rate and high resistance. This absence of effect on mineralization of HA was also reported previously (13). Although this biomaterial does not accelerate the early stage of bone repairing, it is still useful in guided bone regeneration techniques, in which the biomaterials serves as scaffold for membranes, maintaining the space to later new bone formation (3).

The present study aimed to evaluate the early stages of bone defect repairing with hydroxyapatite graft by histological and histomorphometric analysis. The results confirmed the osteoinductive/osteoconductive properties of this grafting material; however, it does not accelerate the bone regeneration. It is possible to suggest that this biomaterial allows complete bone repairing at longer time periods, which needs further investigation to be confirmed.

\section{Acknowledgements}

The authors thank to FAPEMIG (Fundação de Amparo a Pesquisa do Estado de Minas Gerais), to the scholarship granted to the first. 
1. Buser D, Martin W, Belser UC. Optimizing esthetics for implant restorations in the anterior maxilla: anatomic and surgical considerations. Int J Oral Maxillofac Implants 2004:4361.

2. Waasdorp J, Reynolds MA. Allogeneic bone onlay grafts for alveolar ridge augmentation: a systematic review. Int J Oral Maxillofac Implants 2010;3:525-31.

3. Stavropoulos A, Karring ES, Kostopoulos L, Karring T. Deproteinized bovine bone and gentamicin as an adjunct to GTR in the treatment of intrabony defects: a randomized controlled clinical study. J Clin Periodontol 2003;6:486-95.

4. Tapety Fl, Amizuka N, Uoshima K, Nomura S, Maeda T. A histological evaluation of the involvement of Bio-Oss in osteoblastic differentiation and matrix synthesis. Clin Oral Implants Res 2004;3:315-24.

5. Mooren RE, Dankers AC, Merkx MA, Bronkhorst EM, Jansen JA, Stoelinga PJ. The effect of platelet-rich plasma on early and late bone healing using a mixture of particulate autogenous cancellous bone and Bio-Oss: an experimental study in goats. Int J Oral Maxillofac Surg 2010;4:371-8.

6. Cestari TM, Granjeiro JM, de Assis GF, Garlet GP, Taga R. Bone repair and augmentation using block of sintered bovine-derived anorganic bone graft in cranial bone defect model. Clin Oral Implants Res 2009;4:340-50.

7. Jensen SS, Terheyden H. Bone augmentation procedures in localized defects in the alveolar ridge: clinical results with different bone grafts and bone-substitute materials. Int J Oral Maxillofac Implants 2009:218-36.

8. Kubler A, Neugebaver J, Oh JH, Scheer M, Zoller JE. Growth and proliferation of human osteoblasts on different bone graft substitutes: an in vitro study. Implant Dent 2004;2:171-9.

9. Abushahba F, Renvert S, Polyzois I, Claffey N. Effect of grafting materials on osseointegration of dental implants surrounded by circumferential bone defects. An experimental study in the dog. Clin Oral Implants Res 2008;4:329-34.

10. Plachokova AS, van den Dolder J, Stoelinga PJ, Jansen JA. Early effect of platelet-rich plasma on bone healing in combination with an osteoconductive material in rat cranial defects. Clin Oral Implants Res 2007;2:244-51.

11. Deschaseaux F, Pontikoglou C, Sensebe L. Bone regeneration: the stem/progenitor cells point of view. J Cell Mol Med 2010;1-2:103-15.

12. Deschaseaux F, Sensebe L, Heymann D. Mechanisms of bone repair and regeneration. Trends Mol Med 2009;9:417-29.

13. Queiroz TP, Hochuli-Vieira E, Gabrielli MA, Cancian DC. Use of bovine bone graft and bone membrane in defects surgically created in the cranial vault of rabbits. Histologic comparative analysis. Int J Oral Maxillofac Implants 2006;1:29-35.

14. Chiapasco M, Casentini P, Zaniboni M. Bone augmentation procedures in implant dentistry. Int J Oral Maxillofac Implants 2009:237-59.

15. Araujo M, Linder E, Wennstrom J, Lindhe J. The influence of Bio-Oss Collagen on healing of an extraction socket: an experimental study in the dog. Int J Periodontics Restorative Dent 2008;2:123-35.

16. Stavropoulos A, Kostopoulos L, Nyengaard JR, Karring T. Deproteinized bovine bone (Bio-Oss) and bioactive glass (Biogran) arrest bone formation when used as an adjunct to guided tissue regeneration (GTR): an experimental study in the rat. J Clin Periodontol 2003;7:636-43.

17. Yildirim M, Spiekermann H, Biesterfeld S, Edelhoff D. Maxillary sinus augmentation using xenogenic bone substitute material Bio-Oss in combination with venous blood. A histologic and histomorphometric study in humans. Clin Oral Implants Res 2000;3:217-29. 